\title{
TINJAUAN YURIDIS TERHADAPKEJAHATAN KEAMANAN NEGARA DALAM MEDIA SOSIAL INTERNET
}

\author{
Oleh: \\ Syawal Amry Siregar ${ }^{1)}$ \\ Lestari Victoria Sinaga ${ }^{2)}$ \\ Universitas Darma Agung, Medan 1,2) \\ E-mail: \\ $\frac{\text { syawalsiregar59@gmail.com }^{1)}}{\text { missthary35@gmail.com }^{21}}$
}

\begin{abstract}
Privacy and State Secrets can be destroyed by cyber secret scientists who can cause widespread unrest in society. This research uses a normative juridical method that is reviewing the laws and regulations namely Law number 19 of 2016 concerning ITE (Electronic Information and Transactions), Law No. 3 of 2002 concerning National Defense. Based on the results and conclusions obtained, the trend of the threat of cyber attacks will develop in accordance with the development of information technology so that Law No. 3 of 2002 concerning National Defense can be provided about defense in the State defense system consisting of military and non-military security that also uses cyber.
\end{abstract}

Keywords: Crime, State Security, Cyber

\begin{abstract}
ABSTRAK
Privasi dan rahasia Negara dapat dihancurkan oleh para pelaku kejahatan cyber yang dapat membuat keresahan meluas pada masyarakat. Penelitian ini menggunakan metode yuridis normatif yakni mengkaji peraturan perundang-undangan yaitu UU nomor 19 Tahun 2016 tentang ITE, UU No 3 Tahun 2002 tentang Pertahanan Negara. Adapun hasil dan kesimpulan yang didapat adalah Trend ancaman serangan cyber akan berkembang sesuai dengan perkembangan informasi teknologi sehingga dalam UU Nomor 3 Tahun 2002 tentang Pertahanan Negara dapat ditetapkan bahwa ancaman dalam sistem pertahanan Negara terdiri dari ancaman militer maupun non militer seperti juga ancaman cyber.
\end{abstract}

\section{Kata Kunci: Kejahatan, Keamanan Negara, Cyber}

\section{PENDAHULUAN}

Adapun terhadap jenis rahasia diluar itu, sepanjang dikirim atau dterima melalui jaringan elektronik, tetap tunduk pada UU ITE.Keberadaan pengaturan tentang rahasia negara diharapkan dapat mempertegas jaminan keamanan terhadap rahasia negara yang dikirim dan/atau diterima melalui jaringan/sistem elektronik.Ancaman dari dalam negeri merupakan masalah keamanan yang dihadapi oleh negara-egara berkembang.

Tindak pidana terhadap keamanan Negara berkaitan dengan kepentingan hukum atas keselamatan dan keamanan negara di sebuah negara. Usaha menjaga kepentingan hukum akan keselamatan dan keamanan negara merupakan faktor penting dalam mengantarkan suatu bangsa pada kehidupan yang di cita-citakan yaitu nyaman, tentram, adil dan makmur. Akan tetapi seringkali negara salah dan subyektif dalam menafsirkan perbuatan-perbuatan yang dianggap melanggar kepentingan hukum atas keamanan negara tersebut.

Tindakan makar untuk membunuh, atau merampas kemerdekaan, atau meniadakan kemampuan terhadap seorang 
Presiden atau Wakil Presiden dalam melaksanakan pemerintahan, diancam dengan pidana mati atau pidana penjara seumur hidup atau pidana penjara sementara paling lama dua puluh tahun. Makar tersebut supaya seluruh atau sebagian wilayah negara jatuh ke tangan musuh atau memisahkan sebagian dan wilayah negara, diancam dengan pidana penjara seumur hidup atau pidana penjara sementara paling lama dua puluh tahun.

\section{TINJAUAN PUSTAKA}

Dalam Kamus Besar Bahasa Indonesia (KBBI), salah satu pengertian makar adalah perbuatan atau usaha menjatuhkan pemerintahan yang sah. Tindak pidana makar diatur dalam Buku Kedua KUHP (Kejahatan) pada Bab I tentang Kejahatan Terhadap Keamanan Negara dalam pasal 104 sampai pasal 129.Apabila ditelusuri, dalam pengertian sempit, makar meliputi kejahatan terhadap Presiden dan Wakil Presiden, kejahatan terhadap pemerintah atau badan-badan pemerintah dan pemberontakan.

Kejahatan terhadap keamanan negara adalah suatu kejahatan yang menyerang kepentingan hukum negara.Sesuai dengan namanya, kejahatan ini mempunyai obyek keamanan negara.

Dibentuknya kejahatan ini adalah ditujukan untuk melindungi kepentingan hukum atas keselamatan dan keamanan negara dari perbuatan-perbuatan yang mengancam, mengganggu dan merusak kepentingan hukum negara.Ketertiban hukum yang harus dilindungi dalam aturan tentang kejahatan terhadap keamanan negara itu adalah keamanan kepala negara, keamanan wilayah negara, keamanan bentuk pemerintahan.Kejahatan terhadap keamanan negara secara sosiologis disebut kejahatan politik.

Rumusan pasal 87 KUHP, pasal tersebut ternyata merujuk pasal 53 KUHP yang mengatur tentang percobaan (poging). Pasal 53 ayat (1) KUHP berbunyi : "Mencoba melakukan kejahatan dipidana, jika niat untuk itu telah ternyata dari adanya permulaan pelaksanaan, dan tidak selesainya pelaksanaan itu, bukan semata-mata disebabkan karena kehendaknya sendiri."Pasal 87 KUHP tentang tindak pidana makar cukup memuhi unsur niat/maksud (voornemen) dan unsur permulaan pelaksanaan.

Dengan mengacu pada ketentuan pasal tersebut, dapat disimpulkan bahwa terdapat beberapa unsur penting dalam Pasal 53 ayat (1), yaitu adanya niat/maksud (voornemen), permulaan pelaksanaan dan pelaksanaan tidak selesai bukan karena kehendak sendiri. Ketiga syarat ini bersifat kumulatif sehingga ketiganya harus terpenuhi seluruhnya agar seseorang dapat didakwa melakukan percobaan melakukan kejahatan.

Kedua pasal ini (pasal 87 dan pasal 53 ayat (1) KUHP) memang mengatur dua hal yang substansinya berbeda.Namun demikian, unsur-unsur pasal 87 KUHP (unsur niat dan unsur permulaan pelaksanaan) merupakan unsur-unsur yang juga terdapat dalam pasal 53 ayat 1 KUHP.Dengan demikian, doktrin dalam ilmu hukum pidana yang menjelaskan unsur niat dan unsur permulaan pelaksanaan dalam pasal 53 ayat (1) KUHP juga berlaku bagi pasal 87 KUHP sebagaimana ditegaskan dalam pasal 87 KUHP itu sendiri.

\section{METODE PENELITIAN}

Data sekunder yang digunakan adalah berbagai peraturan perundang-undangan yang terkait dengan penelitian ini, meliputi:

1) Bahan Hukum Primer, diantaranya UUD 1945; Undang-undang Nomor 2 Tahun 2002 tentang Kepolisian Republik Indonesia; Kitab Undang-undang Hukum Pidana (KUHP).

2) Bahan Hukum Sekunder, seperti Jurnal Hukum, dan penelitian yang 
berkenaan dengan pembahasan pertahanan dan keamanan dalam media sosial.

3) Bahan Hukum Tersier, yaitu bahan yang dapat mendukung bahanbahan hukum premier dan sekunder, antara lain kamus hukum, kamus bahasa Indonesia, majalah, jurnal ilmiah dan sebagainya

\section{HASIL DAN PEMBAHASAN}

Sejarah Indonesia juga mencatat bawa operasi-operasi militer yang dilakukan Tentara Nasional indoensia sebagaian besar adalah oeprasi-operasi militer untuk mengatasi ancaman dari dalam negeri. Adapun operasi militer yang dilakukan TNI menghadapi kekuatan militer negara lain baru 2 kali dilaksanakan yakni pada peristiwa agresi militer Belanda I Tanggal 21 Juli 1947 dan Peristiwa agresi militer Belanda II pada tanggal 19 Desember 1948.

Dalam istilah taktik militer, posisi Indonesia adalah berada tidak dikehendaki terlebih lagi oleh negara-negara maju.Di masa itu sebelum reformasi, operasi keamanan dalam negeri dipahami sebagai salah satu bentuk oeperasi militer yakni pola operasi militer untuk menghadapi ancaman bersenjata dari dalam negeri.Hal itu didasarkan pada pengertian bahwa ancaman yang dihadapi adalah ancaman terhadap keamanan negara yakni kedaulatan da kutuhan wilayah.Namun setelah reformasi digunakan istilah keamanan dalam negeri tetapi seabgai keamanan publik.

Kejahatan terhadap keamanan negara adalah kejahatan yang menyerang kepentingan hukum negara.Sesuai dengan namanya, kejahatan ini mempunyai obyek keamanan negara.Lebih tepat apabila disebut sebagai Kejahatan Terhadap Pelestarian Kehidupan Negara, karena yang dijaga di sini adalah berlangsungnya kehidupan bernegara, atau Kejahatan Tata negara.
Dibentuknya kejahatan ini adalah ditujukan untuk melindungi kepentingan hukum atas keselamatan dan keamanan negara dari perbuatan-perbuatan yang mengancam, mengganggu dan merusak kepentingan hukum negara.

Ada ketertiban hukum yang harus dilindungi dalam aturan tentang kejahatan terhadap keamanan negara itu. Ketertiban hukum tersebut meliputi:

- Keamanan kepala negara

- Keamanan wilayah negara

- Keamanan bentuk pemerintahan.

Kejahatan terhadap keamanan negara secara sosiologis disebut Kejahatan politik Kata politik berasal dari bahasa Yunani "politia" artinya "segala sesuatu yang berhubungan dengan negara atau segala tindakan, kebijaksanaan, siasat mengenai pemerintahan suatu negara".

$\begin{array}{ccc} & \text { Pengertian yang di dapat dalam } \\ \text { kaitan keamanan negara } & \text { selalu }\end{array}$ berhubungan dengan istilah lain yaitu keamanan nasional karena tidak ada pengertian yang baku tentang keamanan negara dari yang ada di dalam KUHP.

Dalam kaitannya dengan tindak pidana makar, seseorang misalnya baru dapat dapat dimintakan pertanggungjawaban pidana atas ketentuan Pasal 107 KUHP apabila dalam proses hukum terbukti bahwa yang bersangkutan mengetahui dan menghendaki tergulingnya pemerintah. Sementara itu, agar dapat dijerat ketentuan pasal $104 \mathrm{KUHP}$, pelaku harus terbukti mengetahui dan menghendaki terbunuhnya atau hilangnya kemampuan presiden memerintah. Berbagai tayangan yang berapa waktu belakangan ini menjadi viral boleh saja dijadikan salah satu alat bukti, tapi tentunya diperlukan bukti-bukti lain untuk membuktikan terpenuhinya unsur niat ini secara objektif.

Pada media sosial adalah pemblokiran pasal mengenai pemblokiran 
berpotensi abuse lantaran pemerintah memiliki wewenang penuh untuk melakukan pemblokiran tersebut. Dengan adanya Undang-undang Nomor 19 Tahun 2016 yang baru masyarakat memahami hal apa saja yang tidak boleh ditulis dan dibagikan (share) melalui media sosial. Masyarakat juga harus bijak dalam menggunakan media sosial dengan berpikir ulang atas informasi apa yang ingin dibagikan ke orang lain yang nantinya akan dibagikan juga oleh orang lain tersebut.

Kejahatan Keamanan Negara atau Separatism berasal dari kata separatis, dan isme yakni aliran.Separatis adalah suatu gerakan yang bersifat mengacau dan menghancurkan yang dilakukan oleh gerombolan pengacau yang bertujuan untuk memisahkan diri dari ikatan suatu Negara.Orang atau kelompok ini disebut separatis.Mereka berupaya mendapatkan kedaulatan sebagai bangsa atau kelompok yang merdeka.

Di Indonesia, ada dikenal GAM atau Gerakan Aceh Merdeka, RMS atau Republik Maluku Selatan, OPM atau Organisasi Papua Merdeka, dan lainnya yang mau memisahkan dirinya dari Negara kesatuan republik Indonesia, dan ada yang sudah berhasil yakni Timor Leste yang dulunya bernama Timor Timur. lain:

Data gerakan separatism, antara

\section{Organisasi Papua Merdeka (OPM)}

Organisasi Papua Merdeka (OPM) adalah sebuah organisasi yang didirikan tahun 1965 dengan tujuan membantu dan melaksanakan penggulingan pemerintahan yang saat ini berdiri di provinsi Papua dan Papua Barat di Indonesia, sebelumnya bernama Irian Jaya, memisahkan diri dari Indonesia, dan menolak pembangunan ekonomi dan modernitas.

Organisasi ini mendapatkan dana dari pemerintah Libya pimpinan Muammar Gaddafi dan pelatihan dari grup gerilya
New People's Army beraliran Maois yang ditetapkan sebagai organisasi teroris asing oleh Departemen Keamanan Nasional Amerika Serikat.

Organisasi ini dianggap tidak sah di Indonesia. Perjuangan meraih kemerdekaan di tingkat provinsi dapat dituduh sebagai tindakan pengkhianatan terhadap negara.Sejak berdiri, OPM berusaha mengadakan dialog diplomatik, mengibarkan bendera Bintang Kejora, dan melancarkan aksi militan sebagai bagian dari konflik Papua.

$$
\text { Para pendukungnya sering }
$$
membawa-bawa bendera Bintang Kejora dan simbol persatuan Papua lainnya, seperti lagu kebangsaan "Hai Tanahku Papua" dan lambang nasional.Lambang nasional tersebut diadopsi sejak tahun 1961 sampai pemerintahan Indonesia diaktifkan bulan Mei 1963 sesuai Perjanjian New York.

\section{Gerakan Aceh Merdeka (GAM)}

GAM dilahirkan pada 4 Desember 1976. Sebenarnya GAM sendiri sebagai wahana pergerakan baru didirikan pada $20 \mathrm{Mei}$ 1977.Namun Hasan Tiro sendiri memilih hari lahir GAM adalah pada tanggal yang disebut paling awal, disesuaikan dengan proklamasi kemerdekaan Aceh Sumatera. Proklamasi ini dilangsungkan di Bukit Cokan, pedalaman Kecamatan Tiro, Pidie.Prosesi ini dilakukan secara sederhana, dilakukan di suatu tempat yang tersembunyi, menandakan bahwa awalawalnya, gerakan ini adalah gerakan bawah tanah yang dilakukan secara diamdiam.

Terdapat berbagai pendapat yang telah menjelaskan beberapa hal yang menjadi kausa peristiwa ini.Pertama, bahwa GAM merupakan lanjutan perjuangan - atau setidaknya terkait - Darul Islam (DI) Aceh yang sebelumnya pernah meletus pada 1950-an.

Kedua, faktor ekonomi, yang berwujud ketidakadilan dan ketimpangan ekonomi 
antara pusat dengan daerah.Pemerintahan sentralistik Orde Baru menimbulkan kekecewaan berat terutama di kalangan elite Aceh. Pada era Soeharto, Aceh menerima $1 \%$ dari anggaran pendapatan nasional, padahal Aceh memiliki kontribusi 14\% dari GDP Nasional.

\section{Republik Maluku Selatan (RMS)}

Pemberontakan Andi Azis, Westerling, dan Soumokil memiliki kesamaan tujuan yaitu, mereka tidak puas terhadap proses kembalinya RIS ke Negara Kesatuan Republik Indoneisa (NKRI). Pemberontakan yang mereka lakukan mengunakan unsur KNIL yang merasa bahwa status mereka tidak jelas dan tidak pasti setelah KMB.Pemberontakan RMS yang didalangi oleh mantan jaksa agung NIT, Soumokil bertujuan untuk melepaskan wilayah Maluku dari Negara Kesatuan Republik Indonesia.

Cybercrime merupakan salah satu masalah di Indonesia yang ruang lingkupnya berasal dari hukum global internasional.Peningkatan angka kejahatan di dunia maya dipengaruhi oleh faktor dari kausalitas yang sulit untuk mendapatkan bukti oleh aksi dunia maya. Ketika internet menjadi mudah diakses setiap orang, mereka dapat melakukan apa saja dengan berburu dari target. Misalnya, internet banking, hacker, pencarian, dapat memecahkan data aturan sebagaimana telah diubah menjadi data palsu.kejahatan siber merupakan masalah umum yang kita harus selesaikan dengan aturan hukum yang serius. Sebagai instrument pengatur bidang pertahanan kemanan, ada undangundang yang mengatur yakni Pasal 30 Undang-undang Dasar 1945, Undangundang Nomor 2 tahun 2002 tentang Kepolisian Negara, Undang-undang Nomor 3 Tahun 2002 tentang Pertahanan Negara dan Undang-undang Nomor 34 tahun 2004 tentang tentara Nasional Indonesia.

Keamanan nasional adalah terjaga dan terlindunginya kedaulatan Negara, keutuhan wilayah Negara kesatuan wilayah Negara dan keselamatan Indonesia.Dalam konteks ini yang dimaksud adalah keamanan atas suatu entitas sistem yang ada dialam nya sekurang-kurangnya terdapat sistem pemerintahan sistem territorial dan sistem warga Negara.Berdasarkan undang-undang nomor 3 tahun 2002 tentang pertahanan Negara upaya menjaga dan melindungi Negara disebut istilah pertahanan Negara. Lengkapnya pasal 4 UU No 3 Tahun 2002 menyatakan:

"Pertahanan Negara bertujuan untuk menjaga dan melindungi kedaulatan Negara, keutuhan wilayah Negara kesatuan Republik Indonesia dan keselamatan segenap bangsa dari segala bentuk ancaman".

Upaya pertahanan Negara diperlukan agar Negara kesatuan RI terjaga dan terlindungi dari ancaman terhadapnya baik yang berasal dari luar negeri maupun dalam negeri. Yang dimaksud ancaman dalam negeri adalah pemberontakanpemberontakan bersenjata bisa juga ancaman dari kekuatan di luar negeri. Dukungan juga dapat diperoleh dari dukungan politik, dukungan dana, bahkan dukungan persenjataan.

Kekuatan dari luar negeri juga merupakan lembaga yang tidak mempresentasekan pemerintah Negara tertentu di mana lembaga tersebut berada. Seperti pemerbentokan PRRI di Sumatera Barat pada akhir tahun 1950 an, pemberontak G30 S/PKI pada tahun 1965 dan pemberontakan gerakan Spearatis Aceh yang menyebut dirinya gerakan Aceh Merdeka. Ancaman-ancaman tersebut dikatakan berasal dari dalam negeri karena actor-aktor utamanya adalah warga Indonesia sendiri sedang para pendukung dari luar negeri hamper-hampir tidak pernah menyatakan dukungannya secara terang-terangan.

Ancaman dari dalam negeri merupakan masalah ekamanan yang 
banyak dihadapi Negara-negara berkembang. Sejarah Indonesia mencatat bahwa operasi-operasi militer yang dilakukan tentara nasional Indonesia adalah operasi-operasi militer untuk mengatasi ancaman dari dalam negeri. Adapun operasi militer yang dilakukan oleh TNI menghadapi kekuatan militer negrar lain baru 2 kali dilaksanakan yaitu peristiwa agresi militer belanda 1 pada tanggal 21 juli 1947 dan peristiwa agresi militer belanda 2 pada tanggal 3 desember 1948.

Perbuatan yang dilarang dalam Pasal 28 ayat (2) UU ITE ialah dengan sengaja dan tanpa hak menyebarkan informasi yang ditujukan untuk menimbulkan rasa kebencian atau permusuhan individu dan/atau kelompok masyarakat tertentu berdasarkan suku, agama, ras, dan antargolongan (SARA).

Bunyi Pasal 28 ayat (2) UU ITE adalah sebagai berikut:

Setiap Orang dengan sengaja dan tanpa hak menyebarkan informasi yang ditujukan untuk menimbulkan rasa kebencian atau permusuhan individu dan/atau kelompok masyarakat tertentu berdasarkan atas SARA.

Tujuan pasal ini adalah mencegah terjadinya permusuhan, kerusuhan, atau bahkan perpecahan yang didasarkan pada SARA akibat informasi negatif yang bersifat provokatif.Isu SARA dalam pandangan masyarakat merupakan isu yang cukup sensitif.Oleh karena itu, pasal ini diatur dalam delik formil, dan bukan delik materil.

\section{Pasal 28 ayat 2 UU ITE:}

Setiap Orang dengan sengaja dan tanpa hak menyebarkan informasi yang ditujukan untuk menimbulkan rasa kebencian atau permusuhan individu dan/atau kelompok masyarakat tertentu berdasarkan atas suku, agama, ras, dan antargolongan (SARA).

Sebenarnya, tujuan pasal ini adalah mencegah terjadinya permusuhan, kerusuhan, atau bahkan perpecahan yang didasarkan pada SARA akibat informasi negatif yang bersifat provokatif.Isu SARA dalam pandangan masyarakat merupakan isu yang cukup sensitif.Oleh karena itu, pasal ini diatur dalam delik formil, dan bukan delik materil.

Pasal 28 ayat (2) UU ITE tersebut diatur dalam Pasal 45 ayat (2) UU ITE yaitu pidana penjara paling lama 6 (enam) tahun dan/atau denda paling banyak Rp1.000.000.000 (satu miliar rupiah). Efektivitas pasal tentunya dapat dilihat dari setidaknya dua sisi, yaitu pengaturan dan penerapan/penegakan (law enforcement).

Bunyi pasal 45A ayat 2 tersebut adalah

'Setiap Orang yang dengan sengaja dan tanpa hak menyebarkan informasi yang ditujukan untuk menimbulkan rasa kebencian atau permusuhan individu dan/atau kelompok masyarakat tertentu berdasarkan atas suku, agama, ras, dan antargolongan (SARA) sebagaimana dimaksud dalam Pasal 28 ayat (2) dipidana dengan pidana penjara paling lama 6 (enam) tahun dan/atau denda paling banyak Rp1.000.000.000,00 (satu miliar rupiah).

Atas pasal ini Pengadilan negeri Jakarta Selatan mempidanakan Ahmad Dhani Prasetyo atas dakwaan makar dalam media sosial yang dikenakan Pasal 45 A ayat 2 jo Pasal 28 ayat 2 Undang-undang Nomor 19 Tahun 2016 tentang Informasi dan Transaksi Elektronik (ITE) juncto Pasal 55 ayat (1) ke-1 Kitab Undang-undang Hukum Pidana (KUHP).

Kasus Ahmad Dhani bermula dari laporan yang diajukan Jack Boyd Lapian. Jack yang mengklaim sebagai pendukung Basuki Tjahaja Purnama alias Ahok ini 
melaporkan unggahan Dhani di akun Twitter@AHMADDHANIPRAST.

Kicauan Ahmad Dhani di Twitter berisi kebencian.Dalam akun tersebut Dhani menulis, Siapa saja yang dukung penista agama adalah bajingan yang perlu diludahi mukanya.

Undang-undang Nomor 14 tahun 2008 tentang Keterbukaan Informasi Publik dalam Pasal 17 mengatur jenis-jenis dokumen yang dikecualikan kewajiban dibuka kepada publik. Dalam konteks rahasia negara, KUHP mendefinisikan rahasia negara dengan merumuskan frasa "dirahasiakan untuk kepentingan negara". Terhadap rumusan ini masih memerlukan penjelasan apa yang dimaksud dengan kepentingan negara.

Pasal 2 ayat (4) Jo Pasal 17 Undang-Undang Nomor 14 Tahun 2008 tentang Keterbukaan Informasi Publik. Definisi rahasia negara, perlu dibuat definisi atau batasan pengertian yang jelas tentang apa yang dimaksud dengan rahasia negara. Adapun dalam merumuskan definisi atau batasan pengertian tersebut, perlu memperhatikan praktik penggunaan istilah rahasia negara dalam penyelenggaraan pemerintahan yang meliputi :

a) Pertahanan dan keamanan negaraUsaha pertahanan dan keamanan negara dilakukan dengan tujuan menjamin kedaulatan dan keutuhan negara. Tegaknya kedaulatan dan keutuhan negara adalah dalam kerangka NKRI.Segala bentuk usaha, kegiatan dalam tindakan pertahanan dan keamanan negara adalah dalam rangka menghadapi ancaman dan gangguan baik yang berasal dari dalam maupun dari luar wilayah Republik Indonesia.

Usaha pertahanan negara dihadapkan kepada adanya ancaman dan gangguan terhadap kedaulatan negara, keutuhan wilayah NKRI dan keselamatan segenap bangsa.Ancaman dan gangguan dimaksud misalnya invasi tentara asing ke dalam wilayah NKRI, atau gerakan separatis yang hendak memisahkan diri dari wilayah NKRI.

Sedangkan usaha keamanan dihadapkan kepada adanya ancaman dan gangguan terhadap ketertiban dan ketentraman masyarakat.Ancaman dan gangguan dimaksud misalnya tindakan kriminal yang meresahkan masyarakat dalam skala nasional maupun lokal.Dalam konteks rahasia negara, bidang pertahanan dan keamanan negara merupakan lingkup paling luas yang memiliki objek rahasia negara.

Substansi rahasia negara tersebut antara lain informasi mengenai strategi pertahanan dan keamanan, dokumen yang memuat strategi pelaksanaan peperangan, informasi jumlah dan komposisi pasukan, dan rencana pengembangan dan keadaan pangkalan pasukan

b) Intelijen Dalam perang konvensional, intelijen terkait erat dengan metode memperoleh informasi tentang sasaran (musuh). Informasi dimaksud biasanya dapat berupa lokasi, kekuatan musuh secara kuantitas, jalur logistik, dan informasi lain yang sekiranya dapat membantu penyerangan yang akan dilaksanakan. Dengan demikian, seberapa besar kekuatan musuh dapat diketahui dengan tepat dan akurat, sehingga ketika serangan dilakukan, kekuatanyang dimiliki penyerang dapat dikerahkan secara efektif dan efisien.Pada saat ini penggunaan intelijen tidak hanya ditafsirkan dalam konteks peperangan melainkan sudah berkembang menjadi metode untuk mendapatkan informasi dan dipergunakan untuk membantu pimpinan dalam mengambil keputusan.

Dalam situasi dan kondisi politik yang labil, institusi pemerintah yang mempunyai tugas-tugas di bidang intelijen akan berusaha mengetahui secara dini gejala dan potensi dalam masyarakat yang dapat menimbulkan keresahan sosial, sehingga penguasa dapat memprediksi dan 
mengambil keputusan dengan tepat.Sejalan dengan uraian tersebut di atas, operasi intelijen bertujuan untuk : memperoleh informasi yang diperlukan untuk melaksanakan strategi nasional pada umumnya serta operasi pertahanan dan keamanan pada khususnya; menghancurkan sumber-sumber infiltrasi, subversi dan spionase yang terdapat di wilayah musuh; dan mengadakan perang urat syaraf dan kegiatan-kegiatan tertutup lainnya untuk mewujudkan kondisi operasi yang menguntungkan.

Pemerintah juga memberikan perhatian pada masalah keamanan informasi sehingga membentuk ID SIRTI, Polri juga membentuk Cyber Task Force Center disampung ada juga ID CERT sebagai institusi independen yang bertujuan melakukan sistem keamanan teknologi informasi.

Informasi yang telah diolah dan akan menjadi bahan masukan bagi pengambil keputusan, merupakan informasi penting yang harus diperlakukan secara khusus dan hati-hati.

Artinya, informasi tersebut tidak seorang pun boleh mengetahuinya, kecuali hanya pejabat pengambil keputusan yang bersangkutan.Dalam konteks kenegaraan, pejabat pengambil keputusan tertinggi adalah Kepala Negara, sehingga pengguna informasi intelijen tersebut adalah Kepala Negara. Dengan demikian, dapat dipahami apabila informasi intelijen merupakan informasi yang wajib diperlakukan sebagai informasi Rahasia Negara.

Beberapa dasar hukum dalam KUHP yang digunakan aparat penegak hukum yakni Pasal 167 KUHP, Pasal 406 ayat 1 KUHP, Pasal 282 KUHP, Pasal 362 dan 372 KUHP. KUHP masih dijadikan dasar hukum menjaring cyber crime khususnya jenis cyber crime yang memenuhi pasal-pasal di KUHP.
Tindak pidana yang ada di UU ITE adalah Pasal 27 ayat 1, Pasal 27 ayat 3, dan Pasal 28 ayat 2 mengenai SARA.

Pengaturan kebijakan keamanan Negara dalam sistem informasi memang memegang peranan penting dalam mengatur aktivitas dunia maya termasuk pemberian sanksi dan aktivitas jahat yang merugikan.Sehingga pertahanan cyber dapat membahayakan Negara secara nyata baik kelompok tertentu.

\section{SIMPULAN DAN SARAN}

A Kesimpulan

1. Kejahtan terhadap keamanan Negara adalah menyerang kepentingan hukum Negara. Bentuk-Bentuk Kejahatan Terhadap Keamanan Negara Dalam Media Sosial Internet adalah mengenai permufakatan jahat untuk melakukan kejahatan menurut Pasal 104-108,mengadakan hubungan dengan Negara asing dengan maksud melakukan perbuatan permusuhan atau perang terhadap Negara seperti Pasal 111, tindakan makar dengan pasal 104, 105, 106, 107 .

\section{B. SARAN}

1. Seharusnya peringatan bahwa pendidikan etika atau budi pekerti harus kembali dipandang sangat penting melalui sekolah. Sebab, semua yang telah melakukan makar verbal seperti ingin membunuh atau mencacimaki dan menghina Presiden sebagai Kepala Negara dapat dipastikan tidak punya sopan santun lagi.

\section{DAFTAR PUSTAKA}

\section{A Buku- Buku}

Anwar, Mochamad, 1994, Hukum Pidana Bagian Khusus (KUHP), Citra Aditya Bakti, Bandung.

Arief, Barda Namawi,2006, Pedmana Perumusan/ Formulasi Ketentuan 
Pidana dalam Perundang-undangan , Yogyakarta: Fakultas Hukum Universitas Islam Indonesia.

Budi Raharjo, 2004, Keamanan Sistem Informasi Berbasis Internet, Handbook Keamanan, Jakarta, PT Insan Indonesia-Bandung \& PT. Indocisc.

Teknologi Informasi, Jakarta, Elexmedia Komputindo.

Chazawi, Adami, 2009, Hukum Pidana Positif Penghinaan, ITS Press, Surabaya.

Effendi, Erdianto, 2015, Penanggulangan Separatisme Dengan Menggunakan Hukum Pidana, Gentha Publishing, Yogyakarta, 2015.

Lamintang, 1979, Delik-delik Khusus Kejahatan yang Ditujukan terhadap Hak Milik dan Lain-lain hak yang timbul dari Hak Milik, Tarsito, Bandung.

Moeljatno, 1993, Asas-asas Hukum

Pidana, Jakarta, Rineka Cipta.

Mulyadi, Mahmud, 2011, Community Policing : Diskresi dalam Pemoliisan Yang Demokratis, Sofmedia, Jakarta.

Peter Mahmud Marzuki, Penelitian Hukum, Jakarta, Kencana Prenada Media Group, 2005.

Raharjo, Budi, 2002, Memahami Teknologi Informasi, Jakarta, Elexmedia Komputindo.

Renouw, Dian Mega Erianti, 2017, Perlindungan Hukum ECommerce, Yayasan Taman Pustaka, Jakarta.

Sadjijono, 2017, Hukum Kepolisian di Indonesia (Studi Kekuasaan dan Rekontruksi Fungsi Polri dalam Fungsi Pemerintahan), Lakbang Presindo, Jawa Timur.
Simorangkir, J. C. T.,1983, Kamus Hukum, Aksara Baru, 1983

Utrecht, 1960, Hukum Pidana I, Bandung, Penerbit Universitas Padjajaran

\section{B. Peraturan Perundang-undangan}

Kitab Undang-undang Hukum Pidana (KUHP)

Kitab Undang-undang Hukum Acara Pidana (KUHAP)

Undang-undang Nomor 2 tahun 2002 tentang Kepolisian

Undang-undang Nomor 18 Tahun 2003 tentang Advokat

Undang-undang Nomor 24 Tahun 2003 tentang Mahkamah Konstitusi

Undang-undang Nomor 19 Tahun 2016 tentang Informasi dan Transaksi Elektronik

\section{Internet/ Kamus}

Mali, Mahrus, Pencemaran Nama Baik melalui Sarana Informasi dan transaksi Elektronik (Kasus Putusan MK No 2/PUU-VII/2009, Jurnal Konstitusi Volume 7 Nomor 6 Desember 2010, diakses dalam www. 113000-ID-pencemarannama-baik-melalui-sarana-info.pdf pada tanggal 11 Juli 2019.

Anshari, DELIK TERHADAP KEAMANAN NEGARA (MAKAR) DI INDONESIA (Suatu Analisis Yuridis Normatif pada Studi Kasus Sultan Hamid II), Jurnal Hukum \& Pembangunan 48 No. 3 (2018): 457505 ISSN: 0125-9687 (Cetak).

Jawade Hafidz, "Kajian Yuridis Dalam Antisipasi Kejahatan Syber", Jurnal Pembaharuan Hukum Volume 1 No 1 Januari-April 2014.

Mudzakkir, Aspek Hukum Pidana Pasal 27 ayat 3 UU No 11 Tahun 2008 tentang 
ITE yang diselenggarakan dalam DItjen Aplikasi Telekomunikasi Departemen Komunikasi dan Informatika bekerja sama dengan $\mathrm{FH}$ UII Yogyakarta

digital_20283429-T29358-

Analisis\%20penerapan.pdf

https://www.bphn.go.id/data/documents/na _ruu_rahasia_negara.pdf

http://hukum.unsrat.ac.id/mk/mk_14_2008 .pdf

http://ngenespenyebarilmu.blogspot.com/2 016/03/makalah-ancaman-gerakanseparatis-opm.html

http://digilib.uinsuka.ac.id/28568/2/10340128_BABI_IV-atau-V_DAFTARPUSTAKA.pdf

https://news.detik.com/kolom/d4562266/jejak-digital-makarverbaldiakses tanggal 15 Juli 2019.

https://id.wikipedia.org/wiki/Penyelesaian _konflik 